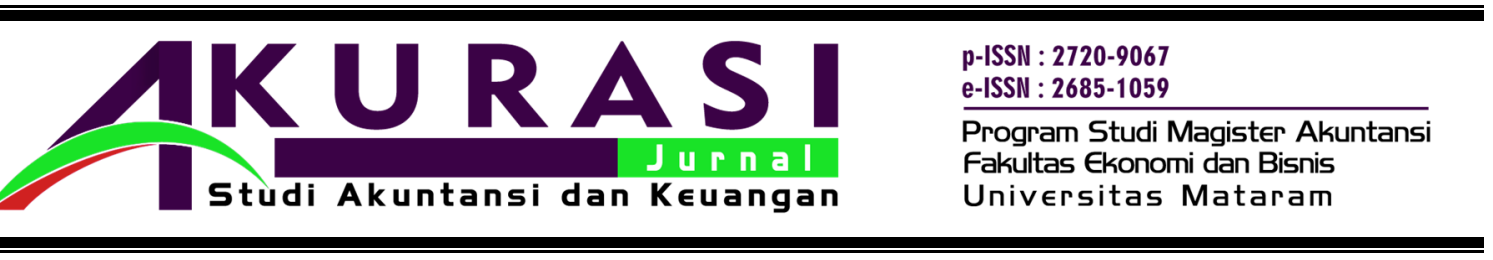

\title{
PENGARUH MANAGERIAL TENURE TERHADAP TAX AVOIDANCE
}

\section{Lalu Andika Noviawan ${ }^{\mathbf{1}}$, Dara Nida Utamie ${ }^{2}$}

Program Studi Magister Akuntansi Universitas Mataram ${ }^{12}$

Corresponding author: laluandika23@gmail.com

\section{INFORMASI ARTIKEL ABSTRAK}

Article history:

Dikirim tanggal: 12/04/2020

Revisi pertama tanggal: 17/05/2020

Diterima tanggal: $04 / 06 / 2020$

Tersedia online: $15 / 6 / 2020$
Tujuan penelitian ini adalah untuk menganalisis hubungan antara managerial tenure terhadap tax avoidance. Return on Asset (ROA) dan leverage dianalisis sebagai variabel kontrol dalam penelitian ini. Pengujian dilakukan pada 65 perusahaan manufaktur di Bursa Efek Indonesia selama periode 2015-2017 dengan Partial Least Square. Hasil penelitian menunjukkan managerial tenure tidak berpengaruh signifikan terhadap tax avoidance. Chief Executive Officer (CEO) tidak melakukan tax avoidance guna mendongkrak reputasinya untuk memperpanjang masa kerja (tenure). Para CEO berupaya meningkatkan kinerja untuk memperoleh kepercayaan pemilik perusahaan, sehingga memperbesar peluang tetap menempati posisinya saat ini. Temuan lainnya penelitian ini adalah bahwa $R O A$ yang dihasilkan perusahaan bukan merupakan pemicu tindakan tax avoidance. Selain itu, leverage tidak memiliki pengaruh terhadap tax avoidance yang mengindikasikan bahwa apapun sumber permodalan yang digunakan perusahaan bukan merupakan upaya menghindari pajak. Implikasi penelitian ini tertuju pada strategi tax avoidance yang menarik sekaligus menguntungkan bagi perusahaan, namun di sisi lain dapat berdampak negatif dan merugikan.

Kata kunci: tax avoidance, managerial tenure, return on assets, leverage

\section{ABSTRACT}

The purpose of this study was to analyze the relationship between managerial tenure and tax avoidance. Return on Assets (ROA) and leverage are analyzed as control variables in this study. Testing was conducted on 65 manufacturing companies on the Indonesia Stock Exchange during the 2015-2017 period with Partial Least Square. The results showed managerial tenure had no significant effect on tax avoidance. The CEO does not do tax avoidance to boost his reputation for extending tenure. The CEOs are trying to improve performance to gain the trust of the company owner, thereby increasing the opportunity to remain in his current position. Another finding of this study is that the ROA produced by the company is not a trigger for tax avoidance. In addition, leverage has no effect on tax avoidance. Any source of capital used by the company is not an attempt to avoid taxes. The implications of this study are focused on tax avoidance strategies that are both attractive and profitable for the company, but on the other hand can have negative and detrimental impacts.

Keywords: tax avoidance, managerial tenure, return on assets, leverage 


\section{Pendahuluan}

Beban pajak yang cukup besar menggerus penghasilan kena pajak perusahaan membuat manajemen lebih cermat dan teliti dalam menganalisis aspek perpajakannya. Salah satu upaya perusahaan untuk menghemat beban pajak yang marak terjadi adalah praktik agresivitas pajak dalam bnetuk tax avoidance. Bukti terbaru menunjukkan bahwa tindakan manajer dirancang untuk mengurangi pajak perusahaan melalui aktivitas agresivitas pajak yaitu suatu skema atau pengaturan yang diberlakukan dengan tujuan utama untuk menghindari pajak (Lanis \& Richardson, 2011). Telah banyak terjadi kasus tax avoidance yang melibatkan perusahaan nasional maupun multinasional melalui berbagai skema. Kasus yang belakangan ramai diberitakan di tanah air mengenai tindakan penghindaran pajak yang dituduhkan kepada PT. Adaro Energy Tbk., salah satu perusahaan batu bara terkemuka di Indonesia. Laporan Global Witness menyebutkan bahwa PT. Adaro Energy melakukan transfer pricing melalui anak usahanya di Singapura, Coaltrade Services International. Adaro memanfaatkan celah dengan menjual batu baranya ke Coaltrade Services International dengan harga yang lebih murah. Batu bara tersebut kemudian dijual ke negara lain dengan harga yang lebih tinggi. Alhasil pendapatan yang dikenakan pajak di Indonesia lebih rendah. Upaya yang dilakukan selama 2009 hingga 2017 membuat perusahaan membayar pajak lebih rendah US\$ 125 juta atau sekitar Rp 1,75 triliun (Sugianto, 2019), dan sampai saat ini proses penyelidikan masih terus berlangsung.

Argumentasi Positive Accounting Theory (Watts \& Zimmerman, 1986) mengungkapkan bahwa kinerja keuangan perusahaan yang sensitif terhadap aspek politik akan diterjemahkan berbeda oleh pihak lain. Manajer pada perusahaan tersebut akan memilih suatu metode akuntansi untuk mengurangi laba agar sensitifitas politiknya berkurang. Perusahaan dengan catatan laba tinggi akan dikenakan pajak yang tinggi sesuai dengan aturan pajak progresif dari pemerintah. Besarnya beban pajak ini membuat manajer berupaya memilih metode akuntansi yang dapat mengurangi beban pajak untuk keuntungan perusahaan. Perusahaan yang melakukan praktikini menjadi perhatian pemerintah karena dapat merugikan negara atas potensi pajak penghasilan yang gagal di pungut sebagai akibat tax avoidance.

Manajer (CEO) pada awal masa jabatannya berusaha menunjukkan kemampuan dan meningkatkan reputasinya dengan cara memilih metode akuntansi untuk meningkatkan laba perusahaan. Pada awal masa jabatannya, ketika market belum memiliki kepastian mengenai kemampuan $C E O$, para $C E O$ ini memiliki dorongan yang lebih besar untuk meningkatkan laba guna mempengaruhi persepsi market (Ali dan Zhang, 2015). Salah satu upaya $C E O$ untuk meningkatkan reputasinya adalah dengan tindakan tax avoidance yang menguntungkan bagi shareholders dan perusahaan secara lebih luas. Keuntungan dari tindakan tax avoidance adalah dapat menghemat pajak dalam jumlah besar (Chen, Chen, \& Shevlin, 2010). Manajer akan memilih suatu metode akuntansi tertentu untuk mengurangi laba kena pajak agar dapat mengurangi beban pajak perusahaan. Kondisi ini akan menguntungkan perusahaan, sehingga reputasi manajer terangkat dan memperbesar peluang untuk tetap menjabat pada posisi $C E O$.

Goldman et al., (2017) dalam penelitiannya memberikan kesimpulan bahwa $C E O$ pada awal kepemimpinannya membuat perusahaannya menghindari pajak untuk meningkatkan laba bersih dan arus kas setelah pajak. Ketika akhir masa kepemimpinannya $C E O$ tersebut 
melakukan penghindaran pajak lebih rendah dari sebelumnya. Noviawan, Handajani, \& Putra (2020) menemukan hasil yang kontradiktif yaitu managerial entrenchment yang diukur dengan tenur manajerial tidak memiliki pengaruh terhadap agresivitas pajak. $C E O$ tidak melakukan agresivitas pajak sebagai strategi untuk mempertahankan posisinya di perusahaan, melainkan untuk mengurangi beban pajak perusahaan. $C E O$ dengan masa kerja yang lama merupakan pendiri perusahaan atau memiliki hubungan afiliasi dengan pemilik perusahaan.

Tujuan penelitian ini adalah untuk menganalisis pengaruh managerial tenure terhadap tax avoidance. Hasil penelitian ini dapat memperkaya literatur mengenai tax avoidance, managerial tenure, return on assets, dan leverage. Penelitian ini juga diharapkan memperkuat positive accounting theory sebagai teori yang mampu menjustifikasi fenomena terkait tax avoidance. Penelitian ini dimotivasi oleh fakta bahwa masih banyak terjadi kasus tax avoidance khususnya oleh perusahaan di Indonesia. Kondisi tersebut sesungguhnya telah direspon oleh pemerintah dengan menerbitkan berbagai peraturan yang termuat dalam Undang-Undang Pajak Penghasilan, SK Menteri Keuangan, Surat Edaran Dirjen Pajak perihal transfer pricing, thin capitalization, controlled foreign corporation, dan treaty shopping. Namun demikian, peraturan tersebut seolah belum mampu mencegah tindakan tax avoidance, sehingga kajian mengenai hal tersebut masih perlu dilakukan. Masih terbatasnya studi mengenai keterkaitan managerial tenure dengan tax avoidance menjadi motivasi lain penelitian ini. Kebaruan penelitian terletak pada penggunaan variabel kontrol yaitu return on assets dan leverage dalam pengujian hubungan managerial tenure dan tax avoidance.

Bagi manajemen perusahaan, penelitian ini diharapkan bisa menjadi bahan evaluasi dan referensi terkait kebijakan dan strategi perpajakan. Strategi penghindaran pajak memang menguntungkan bagi perusahaan karena dapat menghemat pembayaran pajak dalam jumlah besar (Chen et al., 2010), namun di sisi lain dapat merugikan perusahaan seperti risiko dikenakan sanksi oleh otoritas pajak (Desai \& Dharmapala, 2006; Chen et al., 2010) dan biaya besar untuk pembayaran ahli pajak serta denda reputasi (Midiastuty, Suranta, \& Ramdhan, 2017). Temuan penelitian ini juga diharapkan dapat menjadi masukan bagi pemerintah sebagai regulator khususnya Direktorat Jenderal Pajak (DJP) dalam menetapkan peraturan terkait perpajakan. Kajian mengenai peraturan perpajakan harus terus diperbaiki khususnya terkait wajib pajak badan yang dapat memanfaatkan berbagai celah untuk menghindari pajak seperti transfer pricing yang telah diatur dalam Undang-Undang No. 36 Tahun 2008 pasal 18 ayat 3(a).

\section{Kerangka Teoritis dan Pengembangan Hipotesis}

Positive Accounting Theory (Watts \& Zimmerman, 1986) didasarkan adanya dalil bahwa manajer, pemegang saham, dan pemerintah secara rasional berusaha untuk memaksimalkan kepentingan mereka serta berhubungan dengan kompensasi yang diperoleh. Pilihan atas suatu kebijakan akuntansi oleh beberapa kelompok tersebut bergantung pada perbandingan relatif biaya dan manfaat dari prosedur akuntansi alternatif dengan cara demikian untuk memaksimalkan kegunaan mereka (Setijaningsih, 2012). Tiga hipotesis yang disajikan dalam teori ini adalah hipotesis program bonus (bonus plan), hutang/ekuitas (debt covenant), dan biaya politik (political cost). 
Fenomena dalam penelitian ini dapat dijelaskan oleh hipotesis biaya politik (Political Cost Hyphotesis). Hipotesis ini menjelaskan bahwa kinerja keuangan suatu perusahaan secara tidak langsung dapat mempengaruhi bagaimana pihak lain yang terkait menyikapinya. Perusahaan yang sensitif terhadap aspek politik, yaitu cenderung menjadi sorotan banyak orang, besar kecilnya laba yang tercermin dalam angka-angka akuntansi akan diterjemahkan berbeda oleh banyak pihak. Maka, manajer pada perusahan seperti itu memiliki kepentingan untuk menggunakan suatu metode akuntansi tertentu dan memiliki kemungkinan untuk melakukan lobi yang mendukung atau menolak perubahan standar akuntansi yang dapat mempengaruhi sensitifitas politik perusahaan (Setijaningsih, 2012).

Besarnya beban pajak menjadi pemicu manajer melakukan tax avoidance guna meringankan beban perusahaan serta memperoleh keuntungan kas yang lebih besar. Perusahaan manufaktur memiliki kesempatan yang besar untuk melakukan tax avoidance, alasannya proses bisnis yang kompleks meliputi proses produksi, distribusi, dan penjualan yang memungkinkan terjadinya penggelembungan biaya untuk mengurangi laba sebelum pajak. Alasan kedua, banyak perusahaan dalam industri ini yang memiliki afiliasi dengan perusahaan multinasional sehingga berpeluang melakukan berbagai skema tax avoidance seperti thin capitalization, transfer pricing, controlled foreign corporation, dan treaty shopping. Perusahaan-perusahaan ini menjadi perhatian pemerintah karena ada potensi besar kerugian negara yang ditimbulkan oleh tax avoidance. Terbukti dari berbagai kasus penghindaran pajak yang pernah terjadi merugikan negara hingga triliunan rupiah.

Hubungan antara masa kerja manajer (managerial tenure) dan tindakan penghindaran pajak (tax avoidance) telah didiskusikan dalam beberapa studi. CEO (manajer) dengan masa kerja (tenure) yang masih pendek berusaha memberikan keuntungan bagi perusahaan guna meningkatkan reputasinya. Pada awal masa jabatan $C E O$, ketika market belum memiliki kepastian mengenai kemampuannya, $C E O$ memiliki dorongan yang lebih besar untuk meningkatkan laba guna mempengaruhi persepsi market (Ali dan Zhang, 2015). Tax avoidance dapat menghemat pajak dalam jumlah besar (Chen et al., 2010) sehingga sangat menguntungkan bagi perusahaan yang selalu terbebani oleh beban pajak serta porsi kas yang lebih besar dapat dinikmati oleh perusahaan. CEO dapat melakukan tindakan ini untuk mendongkrak reputasinya dalam perusahaan sehingga peluang untuk tetap menjabat pada posisinya semakin meningkat.

Waktu terjadinya tindakan penghindaran pajak selama masa kerja manajer secara spesifik dalam beberapa studi yang relevan. Hasil penelitian Goldman et al. (2017) mengungkapkan temuan bahwa perencanaan pajak tertinggi dilakukan pada saat awal tahun masa kerja (tenure) $C E O$ dan terendah saat akhir masa kerja $C E O$. Hasil penelitian ini mengargumentasikan bahwa pada awal masa kerja kemampuan $C E O$ dipertanyakan, sehingga $C E O$ tersebut berusaha menunjukkan kinerja yang terbaik. $C E O$ berusaha menekan perusahaan untuk menghindari pajak untuk meningkatkan laba bersih dan arus kas setelah pajak. Chyz \& Gaertner (2018) menyatakan CEO yang tidak melakukan tax avoidance yang cukup cenderung lebih berpeluang untuk diberhentikan. Hal ini disebabkan biaya untuk membayar beban pajak yang besar tidak berubah bahkan ketika periode regulator dan otoritas pajak mulai fokus untuk memeriksa perusahaan yang membayar pajak sangat kecil. Berdasarkan argumentasi tersebut diatas diajukan hipotesis bahwa : managerial tenure berpengaruh terhadap tax avoidance. 


\section{Metode Penelitian}

\subsection{Populasi dan Sampel}

Penelitian ini dilakukan dengan pendekatan kuantitatif dengan jenis penelitian kausalitas. Hubungan kausal sebagai hubungan yang bersifat sebab akibat, dalam hal ini ada variabel bebas dan terikat (Sugiyono, 2012). Populasi dalam penelitian ini adalah seluruh perusahaan manufaktur yang terdaftar di Bursa Efek Indonesia tahun 2015-2017. Perusahaan manufaktur dinilai cukup ideal untuk menggambarkan aktivitas tax avoidance, alasannya adalah proses bisnis dalam industri ini cukup kompleks mulai dari proses produksi, distribusi, hingga penjualan. Setiap proses tersebut dapat dimanfaatkan untuk menggelembungkan biaya agar laba sebelum pajak berkurang. Alasan lainnya adalah perusahaan dalam industri ini banyak memiliki afiliasi dengan perusahaan multinasional sehingga menjadi peluang untuk melakukan tax avoidance dengan berbagai skema. Contoh untuk dua alasan tersebut adalah perusahaan dapat memilih untuk membeli bahan baku pada induk perusahaan di luar negeri dengan harga mahal, kemudian menjual kembali barang jadi ke perusahaan yang sama dengan harga murah (transfer pricing). Hal ini membuat beban perusahaan tinggi dan menghasilkan laba yang rendah untuk perhitungan pajak penghasilan. Data penelitian ini menggunakan data kuantitatif yang bersumber dari laporan tahunan (annual report) perusahaan sampel.

Purposive sampling dipilih sebagai teknik pengambilan sampel untuk memperoleh sampel yang dapat mewakili populasi sesuai kriteria yang telah ditentukan.Adapun perusahaan manufaktur yang tidak layak masuk sebagai sampel yaitu: (1) mengalami delisting pada periode 2015 sampai 2017; (2) tidak menerbitkan laporan tahunan secara lengkap selama periode 2015-2017. Dalam hal ini laporan tahunan perusahaan tidak dapat ditemukan pada situs resmi BEI (www.idx.co.id) dan situs resmi perusahaan; (3) laba sebelum pajak negatif (rugi), perusahaan yang mengalami kerugian berarti tidak menanggung beban pajak; (4) menggunakan mata uang asing, agar memiliki kesamaan pengukuran nilai mata uang.

Tabel 1. Perhitungan Sampel

\begin{tabular}{lll}
\hline No. & Kriteria Pemilihan Sampel & Jumlah \\
\hline 1 & $\begin{array}{l}\text { Perusahaan manufaktur yang terdaftar di Bursa Efek Indonesia pada tahun } \\
\text { 2015 - 2017 }\end{array}$ & 142 \\
2 & $\begin{array}{l}\text { Perusahaan manufaktur yang delisting pada periode 2015-2017 } \\
3\end{array}$ & $\begin{array}{l}\text { Perusahaan manufaktur yang tidak menerbitkan laporan tahunan lengkap } \\
\text { selama periode 2015-2017 }\end{array}$ \\
4 & $\begin{array}{l}\text { Perusahaan manufaktur dengan laba sebelum pajak negatif (rugi) dan beban } \\
\text { pajakpositif }\end{array}$ & $(53)$ \\
5 & $\begin{array}{l}\text { Perusahaan manufaktur yang menggunakan mata uang pelaporan } \\
\text { selain rupiah }\end{array}$ & \\
& $\begin{array}{l}\text { Perusahaan yang memenuhi kriteria sampel } \\
\text { Jumlah sampel (65 x 3 tahun) }\end{array}$
\end{tabular}

\subsection{Pengukuran Variabel}

Variabel dependen dalam penelitian ini adalah tax avoidance. Tax avoidance merupakan usaha meringankan beban pajak dengan tidak melanggar undang-undang (Mardiasmo, 2011). Tax avoidance dalam penelitian ini diukur dengan effective tax 
rates (ETR) dan cash effective tax rates (CETR). Nilai ETR dan CETR yang semakin mendekati nol berarti tingkat tax avoidance tinggi, sebaliknya nilai yang semakin besar berarti tax avoidance rendah. Perhitungan ETR dan CETR merujuk pada Chen et al. (2010) yang dihitung dengan rumus berikut :

$$
\text { Effective Tax Rates } \quad=\frac{\text { Beban pajak penghasilan }}{\text { Laba sebelum pajak }}
$$

Cash Effective Tax Rates $=\frac{\text { Pembayaran pajakpenghasilan dengan cash }}{\text { Laba sebelum pajak }}$

Variabel independen dalam penelitian ini adalah managerial tenure. Managerial tenure yaitu lama waktu seseorang menjabat pada posisi pimpinan (Allen, 1981). Managerial tenure dihitung dengan jumlah tahun seseorang menjabat sebagai direktur utama (CEO) di suatu perusahaan (Allen, 1981).

Terdapat dua variabel kontrol dalam penelitian ini yakni return on assets $(R O A)$ dan leverage. Pemilihan kedua variabel kontrol ini bertujuan untuk memutus pengaruh variabel lain yang dapat mempengaruhi tax avoidance sehingga lebih berfokus pada model utama. Alasan lainnya untuk menjawab keraguan mengenai hasil penelitian ini hanya terbatas pada perusahaan dengan kinerja operasional yang tinggi atau perusahaan yang dominan menggunakan liabilitas (hutang) sebagai sumber modal. ROA digunakan untuk mengendalikan kinerja operasional perusahaan, sehingga baik perusahaan dengan kinerja operasional tinggi maupun rendah akan terpenuhi dalam penelitian ini. Leverage digunakan untuk mengendalikan sumber ekuitas perusahaan, sehingga baik perusahaan yang mayoritas menggunakan liabilitas maupun menggunakan modal sendiri (pemegang saham) akan terpenuhi pada penelitian ini.

Return on assets (ROA) menunjukkan kemampuan menghasilkan laba dari aktiva yang dimiliki (Sari, Astuti, Suseno, \& Rahmawati, 2017). ROA digunakan sebagai ukuran kinerja operasional perusahaan (Klapper dan love (2002) dalam Sudiyatno \& Puspitasari, 2010). Merujuk pada Frank, Lynch, \& Rego (2009) perhitungan $R O A$ dalam penelitian ini dihitung dengan rumus sebagai berikut :

$$
\text { Return on Assets }=\frac{\text { Pre Tax Income }}{\text { Total Assets }}
$$

Leverage merupakan kemampuan perusahaan untuk membayar seluruh kewajibannya, baik jangka pendek maupun jangka panjang apabila perusahaan dilikuidasi (Badjuri, 2011). Dalam penelitian ini leverage diukur dengan nilai debt to equity ratio (DER), yaitu perbandingan antara total hutang dengan total ekuitas perusahaan yang dihitung dengan rumus sebagai berikut :

$$
\text { Debt to Equity Ratio }=\frac{\text { Total Utang }}{\text { Total Ekuitas }}
$$




\subsection{Prosedur Analisis Data}

Analisis data dalam penelitian ini menggunakan metode Partial Least Square (PLS). PLS merupakan teknik statistika multivariat yang melakukan pembandingan antara variabel dependen berganda dan variabel independen berganda (Abdillah \& Jogiyanto, 2015). Lebih lanjut, Abdillah \& Jogiyanto (2015) menjelaskan bahwa PLS adalah salah satu metode statistika Structural Equation Modelling (SEM) berbasis varian yang didesain untuk menyelesaikan regresi berganda ketika terjadi permasalahan spesifik pada data, seperti ukuran sampel penelitian kecil, adanya data yang hilang (missing values) dan multikolinearitas. Pemilihan PLS sebagai alat analisis data untuk mengakomodir variabel tax avoidance (dependen) yang menggunakan dua indikator yakni effective tax rates (ETR) dan cash effective tax rates (CETR). Model persamaan penelitian ini sebagai berikut:

TAX_AVO $=\alpha+\beta_{1}$ MAN_TEN $+\beta_{2}$ ROA $+\beta_{3} \mathrm{LEV}+\mathrm{e}$

Keterangan:

TAX_AVO

MAN_TEN : Managerial Tenure

$\mathrm{ROA}^{-} \quad:$ Return on Assets

LEV : Leverage

\section{Hasil dan Pembahasan}

\subsection{Evaluasi Hasil Pengujian Statistik}

Model pengukuran (outer model) dalam penelitian ini dievaluaasi menggunakan convergent validity dan collinearity. Tujuan evaluasi convergent validity adalah untuk melihat hubungan positif antar indikator pada suatu konstruk. Hair, Hult, Ringle, \& Sarstedt (2014) mensyaratkan nilai loading factor tiap indikator $>0,7$. Gambar 1 berikut menjelaskan hasil kalkulasi awal pada model penelitian. Gambar 1 menunjukkan nilai loading factor untuk indikator tenure, ROA, leverage sebesar 1,000 dan CETR sebesar 0,984 artinya tidak terdapat hubungan positif antar indikator. Indikator ETR memiliki loading factor sebesar 0,051 yang lebih rendah dari 0,7, sehingga indikator ini harus dikeluarkan dari model. Nilai loading factor CETR menjadi 1,000 setelah indikator ETR dikeluarkan dari model sebagaimana disajikan pada gambar 2 .

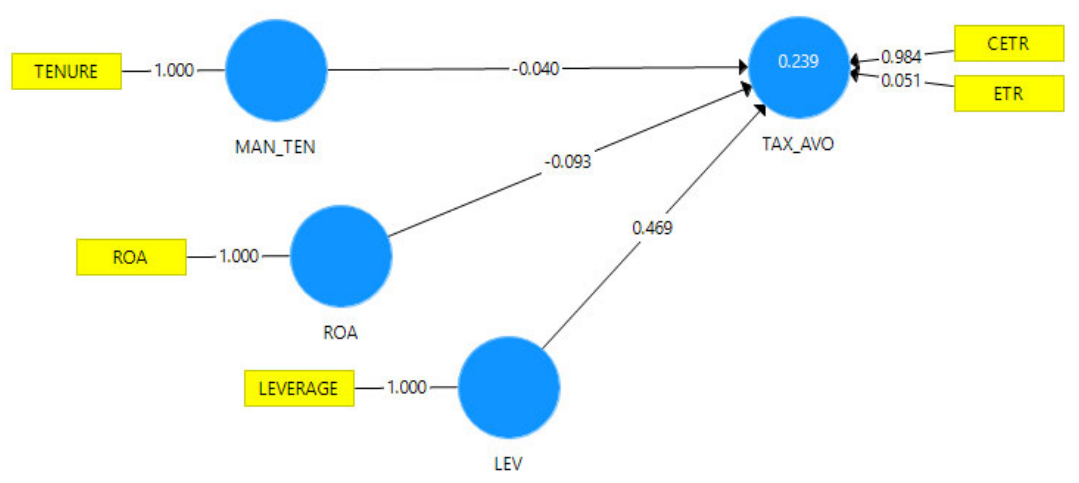

Gambar 1. Hasil Kalkulasi Awal 


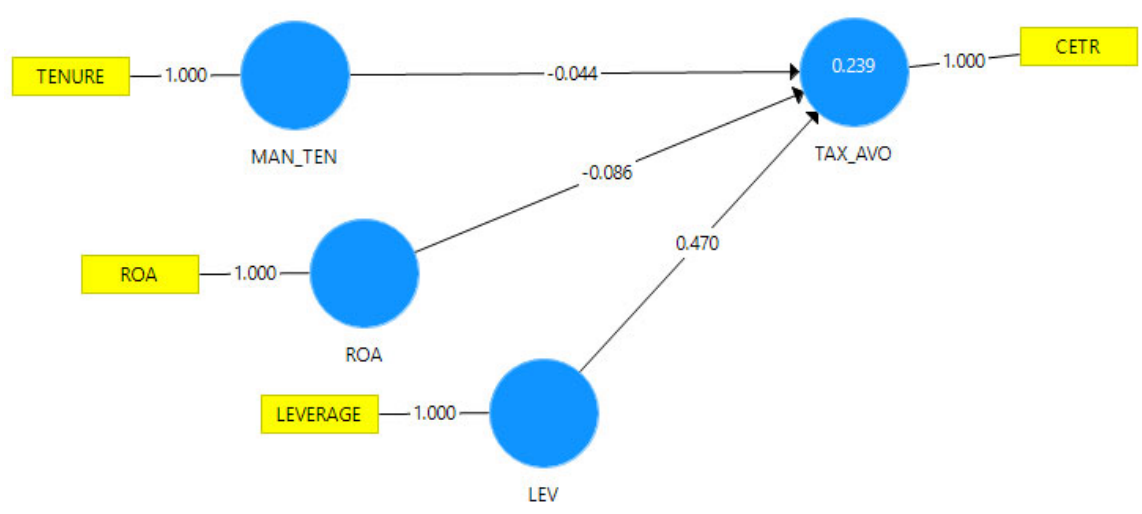

Gambar 2. Hasil Rekalkulasi

Hair et al. (2014) menyatakan kolinearitas yang tinggi antar indikator formatif merupakan isu yang krusial karena dapat berdampak pada estimation of weight dan signifikansi pada statistik. Nilai Variance Inflation Factor (VIF) yang dipersyaratkan (Hair et al., 2014) adalah lebih rendah dari 5. Hasi pengujian collinearity keempat indikator tenure, ROA, leverage dan CETR menunjukkan nilai lebih rendah dari 5. Hal ini berarti tidak terjadi multicollinearity pada keempat indikator formatif.

Nilai outer weight dapat dibandingkan antar indikator dan sebagai penentu kontribusi indikator terhadap konstruk (Hair et al., 2014). Ketika outer weight tidak menampilkan nilai pada $t$ statistics dan $p$ values karena tiap konstruk hanya memiliki satu indikator, maka nilai yang dapat dievaluasi adalah outer loading. Hair et al., (2014) menjelaskan ketika nilai outer weight tidak signifikan, namun nilai outer loading diatas 0,50 (kategori tinggi), maka indikator tersebut layak dipertahankan. Berdasarkan hasil pengujian nilai outer loading keempat indikator tenure, ROA, leverage dan CETR sebesar 1,000 yang dikategorikan tinggi, artinya keempat indikator layak dipertahankan pada model.

Koefisien determinasi $\left(\mathrm{R}^{2}\right)$ merupakan ukuran keakuratan dari suatu model dan untuk menghitung hubungan antara konstruk endogen dengan prediktornya (Hair et al., 2014). Nilai koefisien determinasi berkisar antara 0-1, semakin mendekati 1 maka tingkat prediksi semakin akurat (Hair et al., 2014). Tabel 2 berikut ini menunjukkan nilai koefisien determinasi sebesar 0,239 atau 23,9\%. Hal ini menjelaskan bahwa konstruk tax avoidance dapat dijelaskan oleh konstruk managerial tenure, ROA, dan leverage sebesar 23,9\%, sementara sisanya 76,1\% dijelaskan oleh konstruk lain di luar model penelitian ini.

Tabel 2. Koefisien determinasi $\left(\mathrm{R}^{2}\right)$

\begin{tabular}{rc}
\hline Konstruk & Nilai $^{2}$ \\
\hline Tax Avoidance & 0,239 \\
\hline
\end{tabular}

Pengujian hipotesis dievaluasi berdasarkan nilai path coefficient. Path coefficients berisi informasi untuk pengujian hipotesis sebagaimana disajikan pada tabel 3. Uji hipotesis dapat dilakukan dengan membandingkan nilai $\mathrm{t}$ statistics dengan $\mathrm{t}$ tabel atau membandingkan nilai $p$ values dengan $\alpha$ (taraf signifikansi 5\%). 
Tabel 3 . Path Coefficients

\begin{tabular}{lcrrrr}
\hline & $\begin{array}{c}\text { Original } \\
\text { Sample } \\
(\mathrm{O})\end{array}$ & $\begin{array}{c}\text { Sample } \\
\text { Mean (M) }\end{array}$ & $\begin{array}{c}\text { Standard } \\
\text { Deviation } \\
(\text { STDEV })\end{array}$ & $\begin{array}{c}\text { T Statistics } \\
(\mid \mathrm{O} / \text { STDEV } \mid)\end{array}$ & P Values \\
\hline MAN_TEN $\rightarrow$ TAX_AVO & $-0,044$ & $-0,044$ & 0,037 & 1,177 & 0,240 \\
ROA $\rightarrow$ TAX_AVO & $-0,086$ & $-0,143$ & 0,095 & 0,899 & 0,369 \\
LEV $\rightarrow$ TAX_AVO & 0,470 & 0,394 & 0,246 & 1,911 & 0,057 \\
\hline
\end{tabular}

Hubungan konstruk managerial tenure (MAN_TEN) terhadap tax avoidance (TAX_AVO) menunjukkan nilai $t$ statistics sebesar 1,177 yang lebih kecil dari 1,96 dan nilai $p$ values sebesar 0,240 lebih besar dari 0,05 $(\alpha=5 \%)$. Kondisi ini berarti tidak terdapat hubungan antar kedua konstruk sehingga hipotesis ditolak. Nilai koefisien sebesar -0,044 menunjukkan peningkatan managerial tenure akan menurunkan cash effective tax rates yang berarti meningkatknya tax avoidance. Hasil pengujian terhadap pengaruh variabel kontrol Return on Asset (ROA) dan leverage terhadap tax avoidance menunjukkan hasil yang tidak signifikan karena masing-masing memiliki nilai $p$ values lebih besar dari 0,05 $(\alpha=5 \%)$. Pengaruh ROA terhadap tax avoidance memiliki koefisien negatif, sedangkan pengaruh leverage terhadap tax avoidance memiliki koefisien positif.

\subsection{Pembahasan}

Hasil penelitian ini menemukan bahwa masa jabatan CEO tidak mempengaruhi secara signifikan tindakan tax avoidance. Temuan ini dapat diargumentasikan bahwa $C E O$ pada awal masa jabatannya atau ketika masa kerja (tenure) yang masih pendek tidak melakukan tax avoidance guna meningkatkan reputasinya, namun mereka berusaha mempertahankan posisinya dengan cara peningkatan kinerja. Tabel 4 menunjukkan perusahaan sampel yang mencatatkan ROA tertinggi selama tahun 2015-2017. Berdasarkan informasi pada tabel 4 dapat diketahui bahwa enam dari tujuh perusahaan tersebut mencatat masa jabatan $C E O$ yang relatif pendek. Hal ini mengindikasikan bahwa para $C E O$ tersebut berusaha untuk meningkatkan kinerja dengan memanfaatkan aset semaksimal mungkin untuk menghasilkan laba. Upaya ini diindikasikan merupakan cara yang tepat untuk mengambil kepercayaan para pemilik perusahaan sehingga peluang untuk tetap berada pada posisi $C E O$ menjadi lebih besar.

Tabel 4. Perusahaan Sampel dengan ROA Tertinggi

\begin{tabular}{llcccccc}
\hline \multirow{2}{*}{ No. } & \multicolumn{1}{c}{ Perusahaan } & \multicolumn{2}{c}{2015} & \multicolumn{2}{c}{2016} & \multicolumn{2}{c}{2017} \\
\cline { 3 - 8 } & $\begin{array}{c}\text { Masa } \\
\text { Jabatan }\end{array}$ & ROA & $\begin{array}{c}\text { Masa } \\
\text { Jabatan }\end{array}$ & ROA & $\begin{array}{c}\text { Masa } \\
\text { Jabatan }\end{array}$ & ROA \\
\hline 1 & Multi Bintang Indonesia & 3 & 32,15 & 4 & 58,02 & 5 & 70,91 \\
2 & Unilever Indonesia & 1,1 & 49,77 & 2,1 & 51,18 & 3,1 & 49,56 \\
3 & Taisho Pharmaceutical Indonesia & 1 & 42,80 & 2 & 45,87 & 3 & 48,50 \\
4 & Hanjaya Mandala Sampoerna & 3 & 36,65 & 4 & 40,01 & 5 & 39,16 \\
5 & Selamat Sempurna & 33 & 26,29 & 34 & 29,19 & 35 & 29,49 \\
6 & Merck & 2 & 30,22 & 3 & 28,88 & 4 & 24,29 \\
7 & Delta Djakarta & 5 & 24,09 & 6 & 27,30 & 7 & 27,52 \\
\hline
\end{tabular}


Hasil penelitian ini didukung oleh Noviawan et al. (2020) yang menyimpulkan managerial entrenchment yang diukur dengan tenure manajerial tidak berpengaruh terhadap agresivitas pajak (tax avoidance). CEO tidak melakukan agresivitas pajak untuk mempertahankan posisinya di perusahaan, namun tindakan tersebut hanya untuk mengurangi beban pajak. Para $C E O$ tersebut merupakan pendiri perusahaan atau memiliki hubungan afiliasi dengan pemilik perusahaan. Namun demikian hasil penelitian ini tidak sejalan dengan hasil penelitian Goldman et al., (2017) yang mengargumentasikan bahwa masa kerja CEO berhubungan dengan tindakan perencanaan pajak yang tertinggi pada awal masa kerja dan terendah saat akhir masa kerja $C E O$. Hasil penelitian ini juga tidak sejalan dengan temuan penelitian Chyz \& Gaertner (2018) menyatakan hubungan antara masa kerja CEO dengan tindakan penghindaran pajak, dimana $C E O$ yang tidak melakukan tax avoidance yang cukup cenderung lebih berpeluang untuk diberhentikan.

Penelitian ini dapat memberikan informasi dan sebagai referensi bagi manajer dalam menentukan kebijakan perpajakan perusahaan. Sebaiknya menghindari strategi tax avoidance yang dapat merugikan perusahaan. Bagi Direktorat Jenderal Pajak hasil penelitian ini menjadi masukan untuk terus melakukan evaluasi dan penyempurnaan terkait peraturan perpajakan. Terdapat berbagai celah yang dapat dimanfaatkan perusahaan untuk menghindari pajak seperti thin capitalization, transfer pricing dan lainnya, maka DJP perlu menutup celah tersebut agar dapat memaksimalkan penerimaan negara dari sektor pajak.

Hubungan konstruk return on assets (ROA) terhadap tax avoidance (TAX_AVO) menunjukkan nilai $t$ statistics sebesar 0,899 yang lebih kecil dari 1,96 dan nilai $p$ values sebesar 0,369 lebih besar dari 0,05 $(\alpha=5 \%)$. Hasil ini menunjukkan bahwa ROA tidak memiliki pengaruh signifikan terhadap tax avoidance. Nilai koefisien sebesar -0,086 menunjukkan peningkatan return on assets akan menurunkan cash effective tax rates yang berarti meningkatknya tax avoidance. Return on assets (ROA) dijadikan sebagai ukuran seberapa baik aset perusahaan dapat menghasilkan laba. Ketika perusahaan menggunakan asetnya dengan efektif dan efisien sehingga dapat menghasilkan laba maksimal, maka nilai $R O A$ akan tinggi. Sebaliknya perusahaan yang gagal memanfaatkan asetnya untuk menghasilkan laba, maka $R O A$ dinilai rendah. Hasil penelitian ini menunjukkan bahwa tinggi rendahnya $R O A$ tidak memiliki hubungan dengan tinggi rendahnya tindakan tax avoidance perusahaan. ROA ditentukan oleh kinerja sumber daya manusia dalam memanfaatkan aset untuk menghasilkan laba, sedangkan tax avoidance merupakan pilihan manajer dalam strategi perpajakannya untuk mengurangi beban pajak perusahaan. Ketika perusahaan mampu menghasilkan ROA tinggi, hal tersebut bukan merupakan pemicu manajer untuk melakukan tax avoidance.

Temuan penelitian ini sejalan dengan kesimpulan Marfu'ah (2015) dalam penelitiannya bahwa $R O A$ tidak berpengaruh terhadap tax avoidance. ROA merupakan indikator perusahaan dalam menghasilkan laba sehingga merupakan faktor penting dalam pengenaan pajak penghasilan badan. Hal ini membuat perusahaan merencanakan pajaknya dengan matang sehingga menghasilkan pajak yang optimal dan jauh dari tindakan tax avoidance. Sejalan dengan penelitian ini, hasil penelitian Yuliani, (2018) menyatakan bahwa semakin tinggi ROA, maka semakin tinggi keuntungan perusahaan, hal ini mencerminkan kemampuan yang baik dalam pengelolaan aset perusahaan yang menjadikan perusahaan tidak berusaha untuk menghindari pajak. 
Hubungan konstruk leverage (LEV) terhadap tax avoidance (TAX_AVO) menunjukkan nilai $t$ statistics sebesar 1,911 yang lebih kecil dari 1,96 dan nilai $p$ values sebesar 0,057 lebih besar dari 0,05 ( $\alpha=5 \%)$. Kondisi ini berarti leverage tidak berpengaruh signifikan terhadap tindakan tax avoidance. Nilai koefisien sebesar 0,470 menunjukkan peningkatan leverage akan meningkatkan cash effective tax rates yang berarti menurunnya tax avoidance. Peraturan Menteri Keuangan Republik Indonesia 169/PMK.010/2015 (2015) menyebutkan bahwa besarnya perbandingan antara utang dan modal untuk keperluan perhitungan pajak penghasilan ditetapkan paling tinggi sebesar empat dibanding satu (4:1). Hal ini bertujuan untuk mencegah praktik thin capitalization yaitu praktik membiayai cabang atau anak perusahaan lebih banyak dengan hutang dibandingkan modal sendiri (Rahayu, 2010). Peraturan ini merupakan pembaruan dari peraturan sebelumnya terkait hal yang sama termuat dalam Keputusan Menteri Keuangan No. 1002/KMK.04/1984.

Perbandingan utang dan modal (debt to equity ratio/DER) yang rendah berarti perusahaan lebih banyak menggunakan sumber permodalan dari modal sendiri (penyertaan modal shareholder). Pada akhir tahun sebagian laba akan dibagikan dalam bentuk dividen kepada shareloders tersebut. Dividen ini bukan merupakan pos pengurang pendapatan yang dapat mengurangi beban pajak. Berbeda ketika perusahaan cenderung menggunakan hutang sebagai sumber permodalan (DER tinggi), bunga hutang dapat dijadikan sebagai beban perusahaan yang dapat mengurangi pendapatan sehingga mengurangi beban pajak. Kondisi ini merupakan salah satu skema yang dapat dilakukan perusahaan untuk mengurangi beban pajak (thin capitalization). Meski demikian, penelitian ini menunjukkan leverage tidak berpengaruh terhadap tax avoidance.

Temuan ini mengindikasikan bahwa sumber permodalan yang digunakan perusahaan yang berimbas pada tinggi rendahnya $D E R$ tidak memiliki keterkaitan terhadap tax avoidance. Ketika perusahaan berupaya untuk mengurangi beban pajak, maka mereka akan melakukan berbagai skema selain thin capitalization. Beberapa skema yang dapat dilakukan perusahaan antara lain transfer pricing dengan cara bertransaksi dengan anak perusahaan di luar negeri, treaty shopping untuk menikmati tarif pajak rendah di negara tax heaven, control foreign corporation (CFC) yang dapat menunda pengakuan penghasilan dari luar negeri untuk pengenaannya di dalam negeri.

Hasil penelitian ini sejalan dengan penelitian Darmawan \& Sukartha (2014), Dewinta \& Setiawan (2016) serta Handayani (2017) yang menyimpulkan bahwa leverage tidak berpengaruh terhadap tax avoidance. Keputusan pendanaan perusahaan dapat menjadi gambaran aktivitas penghindaran pajak perusahaan, hal ini terkait adanya peraturan perpajakan yang mengatur kebijakan struktur pendanaan perusahaan. Sumber pendanaan dari hutang akan menghasilkan beban bunga sebagai pengurang beban pajak, sementara modal sendiri menghasilkan dividen yang tidak mengurangi beban pajak. Perusahaan sampel lebih banyak menggunakan modal sendiri dari pemilik saham, sehingga tidak terdapat beban bunga yang signifikan untuk mengurangi beban pajak.

\section{Kesimpulan, Implikasi dan Keterbatasan}

Hasil penelitian ini menunjukkan managerial tenure tidak memiliki pengaruh terhadap tindakan tax avoidance. CEO dengan masa kerja (tenure) pendek tidak melakukan tax 
avoidance guna mendongkrak reputasinya. Para $C E O$ tersebut berupaya meningkatkan kinerja dengan memaksimalkan aset untuk menghasilkan laba. Ketika perusahaan mampu menghasilkan laba maksimal, maka kepercayaan pemilik akan bertambah dan memperbesar peluang untuk tetap menduduki posisi $C E O$. Temuan lain mengungkapkan tinggi rendahnya $R O A$ sebagai indikator kemampuan aset menghasilkan laba tidak berhubungan dengan tinggi rendahnya tax avoidance. ROA ditentukan oleh kemampuan sumber daya manusia dalam memanfaatkan aset untuk menghasilkan laba, sedangkan tax avoidance merupakan tindakan yang dipilih manajer untuk menghindari pajak. Laba tinggi yang dihasilkan perusahaan bukan menjadi pemicu manajer melakukan tax avoidance. Temuan lain penelitian ini mengungkapkan bahwa leverage tidak mempengaruhi tindakan tax avoidance oleh manajer. Hasil ini mengindikasikan bahwa apapun sumber permodalan yang dominan digunakan perusahaan baik hutang maupun modal sendiri, tidak memiliki keterkaitan dengan tindakan tax avoidance. Manajer yang berupaya melakukan tax avoidance dapat menggunakan berbagai skema selain thin capitalization, seperti transfer pricing, treaty shoping atau controled foreign corporation.

Implikasi dari hasil penelitian ini tertuju pada strategi tax avoidance yang dalam jangka pendek menguntungkan perusahaan, namun di saat yang sama atau jangka panjang dapat merugikan perusahaan. Tantangan bagi perusahaan adalah dapat menahan diri untuk tidak melakukan tax avoidance, sementara bagi Dirjen Pajak dapat menyempurnakan regulasi yang dapat menutup celah tindakan tax avoidance. Hasil penelitian ini mengargumentasikan political cost hypothesis dimana perusahaan dengan beban pajaknya tinggi memiliki hubungan politik dengan pemerintah melalui upaya tax avoidance. Peran pengawasan pemerintah diperlukan terhadap perusahaan ini karena dapat merugikan negara akibat potensi pajak penghasilan yang gagal dipungut.

Koefisien determinasi $\left(\mathrm{R}^{2}\right)$ dalam penelitian ini yang sebesar 23,9\% dapat dikategorikan sedang dalam menjelaskan variabel tax avoidance, namun variabel independen dan variabel kontrol tidak ada yang berpengaruh terhadap tax avoidance. Temuan ini cukup menarik, sehingga untuk peneliti selanjutnya dapat menggunakan proksi pengukuran tax avoidance yang berbeda seperti tax avoidance performance-matched (Puspita \& Harto, 2014), book tax gap (Desai \& Dharmapala, 2006), atau discreationary permanent differences/DTAX (Frank et al., 2009). Berkaitan dengan managerial tenure dapat mempertimbangkan indikator rata-rata jumlah tahun masa jabatan dewan direksi (Marlin \& Geiger, 2011) dalam pengukurannya.

\section{Daftar Pustaka}

Abdillah, W., \& Jogiyanto. (2015). Partial Least Square (PLS) Alternatif Structural Equation Modeling (SEM) Dalam Penelitian Bisnis. Yogyakarta: Andi Offset.

Ali, A \& W. Zhang. (2015). CEO Tenure and Earning Management. Journal of Accounting and Economics, 59, 60-79.

Allen, M. P. (1981). Managerial Power and Tenure in The Large Corporation. Social Forces, 60(2), 482-494.

Badjuri, A. (2011). Corporate Governance Mechanism, Fundamental Factors, Corporate Social Responsibility ( CSR ) Disclosure of a Natural Resource And Manufactur Company in Indonesian. Dinamika Keuangan Dan Perbankan, 3(1), 38-54. 
Chen, S., Chen, X., \& Shevlin, T. (2010). Are family firms more tax aggressive than nonfamily firms? . Journal of Financial Economics, 91(1), 414-461.

Chyz, J. A., \& Gaertner, F. . (2018). Can Paying "Too Much" or "Too Little" Tax Contribute to Forced CEO Turnover? The Accounting Review, 93(1), 103-130.

Darmawan, I. G. H., \& Sukartha, I. M. (2014). Pengaruh Penerapan Corporate Governance, Leverage, Return On Asset, dan Ukuran Perusahaan Pada Penghindaran Pajak. E-Jurnal Akuntansi Universitas Udayana, 9(1), 143-161.

Desai, M. A., \& Dharmapala, D. (2006). Corporate Tax Avoidance and High-Powered Incentives. Journal of Financial Economics, 79, 145-179.

Dewinta, I. A. R., \& Setiawan, P. E. (2016). Pengaruh Ukuran Perusahaan, Umur Perusahaan, Profitabilitas, Leverage, dan Pertumbuhan Penjualan terhadap Tax Avoidance. E-Jurnal Akuntansi Universitas Udayana, 14(3), 1584-1613.

Frank, M. M., Lynch, L. J., \& Rego, S. O. (2009). Tax Reporting Aggressiveness and Its Relation to Aggressive Financial Reporting. The Accounting Review, 84(2), 467496.

Goldman, N. C., Powers, K., \& Williams, B. M. (2017). How Does Ceo Tenure Affect Corporate Income Tax Planning and Financial Reporting Decisions? Dallas.

Hair, J. F., Hult, G. T. M., Ringle, C. M., \& Sarstedt, M. (2014). A Primer on Partial Least Square Structural Equation Modeling (PLS-SEM). Los Angeles: SAGE Publications, Inc.

Handayani, R. (2017). Pengaruh Return On Asset (ROA), Leverage, dan Ukuran Perusahaan, terhadap Tax Avoidance Pada Perusahaan Perbankan Yang Listing di BEI Periode Tahun 2012-2015. Jurnal Akuntansi Maranatha, 10(1), 72-84.

Lanis, R., \& Richardson, G. (2011). J . Account . Public Policy The effect of board of director composition on corporate tax aggressiveness. Journal of Accounting and Public Policy, 30(1), 50-70. https://doi.org/10.1016/j.jaccpubpol.2010.09.003

Mardiasmo. (2011). Perpajakan Edisi Revisi. Yogyakarta: Andi Offset.

Marfu'ah, L. (2015). Pengaruh Return On Asset, Leverage, Ukuran Perusahaan, Kompensasi Rugi Fiskal, dan Koneksi Politik Terhadap Tax Avoidance. Universitas Muhammadiyah Surakarta.

Marlin, D., \& Geiger, S. W. (2011). The Composition Of Corporate Boards Of Directors: Pre- And Post-Sarbanes-Oxley. Journal of Business and Economics Research, 9(2), 73-78.

Midiastuty, P. P., Suranta, E., \& Ramdhan, P. M. (2017). Pengaruh Kepemilikan Terkonsentrasi Dan Corporate Governance Terhadap Agresivitas Pajak. Proceedings Simposium Nasional Akuntansi XX. Jember, 1-26.

Noviawan, L. A., Handajani, L., \& Putra, N. N. A. (2020). Pengaruh Komite Audit dan Managerial Entrenchment terhadap Agresivitas Pajak Serta Implikasinya terhadap Kinerja Keuangan Perusahaan. E-Jurnal Akuntansi Universitas Udayana, 30(2), 428-446.

Peraturan Menteri Keuangan Republik Indonesia 169/PMK.010/2015. Penentuan Besarnya Perbandingan Antara Utang dan Modal Perusahaan Untuk Keperluan Penghitungan Pajak Penghasilan. , (2015).

Puspita, S. R., \& Harto, P. (2014). Pengaruh Tata Kelola Perusahaan terhadap Penghindaran Pajak. Diponegoro Journal of Accounting, 3(2), 1-13.

Rahayu, N. (2010). Evaluasi Regulasi Atas Praktik Penghindaran Pajak Penanaman Modal Asing. Jurnal Akuntansi Dan Keuangan Indonesia, 7(1), 61-78.

Sari, S. R., Astuti, T. P., Suseno, A. E., \& Rahmawati. (2017). Kepemilikan Keluarga dan Tindakan Pajak Agresif. Proceedings Simposium Nasional Akuntansi XX. Jember. 
Setijaningsih, H. T. (2012). Teori Akuntansi Positif dan Konsekuensi Ekonomi. Jurnal Akuntansi, 16(3), 427-438.

Sudiyatno, B., \& Puspitasari, E. (2010). Tobin's q dan Altman Z-Score Sebagai Indikator Pengukuran Kinerja Perusahaan. Kajian Akuntansi, 2(1), 9-21.

Sugianto, D. (2019). Mengenal Soal Penghindaran Pajak yang Dituduhkan ke Adaro. Retrieved from www.detik.com website: www.detik.com/finance/berita-ekonomibisnis/d-4612708/mengenal-soal-penghindaran-pajak-yang-dituduhkan-ke-adaro

Sugiyono. (2012). Metode Penelitian Bisnis (Pendekatan Kuantitatif, Kualitatif, dan $R \& D)$. Bandung: Alfabeta.

Watts, R. L., \& Zimmerman, J. L. (1986). Positive Accounting Theory. Prentice Hall International Inc.

Yuliani, V. (2018). Pengaruh Penerapan Corporate Governance, Return On Asset, dan Leverage terhadap Tax Avoidance Pada Perusahaan Manufaktur Yang Terdaftar Di Bursa Efek Indonesia. Jurnal Ekobis Dewantara, 1(2), 31-53. 